\title{
Oil Paintings and Politics: Weaving a Heroic Tale of the Chinese Communist Revolution
}

\author{
CHANG-TAI HUNG \\ The Hong Kong University of Science and Technology
}

"In my entire life I did not produce a single painting that was uppermost in mind to create," the celebrated painter Dong Xiwen (1914-1973) reportedly lamented on his deathbed. ${ }^{1}$ Dong may not have produced the dream piece that he would truly cherish, but he did create, albeit unwillingly, a deeply controversial work of art in his 1953 oil painting The Founding Ceremony of the Nation (Kaiguo dadian) (Figures 1 and 2), for it epitomizes the tension between art and politics in the People's Republic of China (PRC). In this famous piece, Dong portrays Chairman Mao Zedong (1893-1976) in Tiananmen Square on 1 October 1949, with his senior associates in attendance-Liu Shaoqi (1898-1969), Zhu De (1886-1976), Zhou Enlai (1898-1976), Gao Gang (1905-1954), Lin Boqu (1886-1960), and others. They are surrounded by huge lanterns, a Chinese symbol of prosperity, and a sea of red banners that declare the founding of a new nation. When first unveiled in 1953, the painting was widely hailed as one of the greatest oil paintings ever produced by a native artist. ${ }^{2}$ In just three months more than half-a-million reproductions of the painting were sold. ${ }^{3}$ But the fate of this work soon took an ominous turn, and the artist was requested to make three major revisions during his lifetime. In 1954 Dong was instructed to excise Gao Gang from the scene when Gao was purged by the Party for allegedly plotting to seize power and create an

Acknowledgments: The author is grateful to the CSSH reviewers for their valuable suggestions. Research for this article was generously funded by a grant from the Research Grants Council, Hong Kong. Note that color versions of the images in this paper can be viewed online at: http:// www.journals.cambridge.org/jid_css.

1 Liu Xiaochun, ed., Luo Gongliu yishu duihualu (A dialogue about art with Luo Gongliu) (Taiyuan: Shanxi jiaoyu chubanshe, 1999), 119.

2 Bo Songnian, ed., Zhongguo yishushi tuji (A pictorial history of Chinese art) (Shanghai: Shanghai wenyi chubanshe, 2004), 253.

3 Jiang Feng, Jiang Feng meishu lunji (Jiang Feng's collected essays on art) (Beijing: Renmin meishu chubanshe, 1983), Vol. 1, 92. 
"independent kingdom" in Manchuria. During the Cultural Revolution in the mid-1960s Liu Shaoqi was accused of advocating a "bourgeois reactionary line" and subsequently was purged, and Dong was ordered in 1967 to redo his painting again and erased Liu from the inauguration scene. Then, in 1972, also during the Cultural Revolution, the radicals, commonly labeled the "Gang of Four," ordered a third revision, namely, that Lin Boqu be eliminated from the painting for allegedly opposing the marriage of Mao and Jiang Qing (1914-1991) during the Yan'an days. By this time Dong was dying of cancer and was too ill to pick up the brush, so his student Jin Shangyi (b. 1934), and another artist, Zhao Yu (1926-1980), were assigned the task. These two artists, afraid of doing further damage to the original piece, eventually produced a replica of the painting, with the ailing Dong brought from the hospital for consultation on his embattled work. Though Dong died the following year, ${ }^{4}$ the ill-fated story of The Founding Ceremony of the Nation did not end: in 1979, with the demise of the Gang of Four and the Party's official rehabilitation of Liu Shaoqi, the images of Liu, Gao Gang, and Lin Boqu were restored in the painting. Because Jin Shangyi was on a foreign tour, Yan Zhenduo (b. 1940), a graduate of the Department of Oil Painting at the Central Academy of Fine Arts (CAFA), was called upon to help reinstall the three leaders.

Chinese artists were not the first to be ordered by authorities to revise their paintings, and hence rewrite history in order to accommodate the political reality, for this was a long tradition among their Soviet counterparts as well. In 1949, for instance, Sergei Gerasimov repainted his famous 1943 oil painting, The Mother of a Partisan (Russian Museum, St. Petersburg), to give the heroine a more courageous appearance, in conformity with the theory of socialist realism then in vogue in the country. ${ }^{5}$ But few Russian works suffered the fate that befell Dong's painting. In what follows I will argue that, compared to the role of the Soviet Communist Party in rewriting its nation's modern history, the Chinese Communist Party (CCP) was even more decisive in revising modern Chinese history, especially in its use of paintings as a key means of persuasion. The CCP realized that seizing power was more than a political and military campaign; perhaps even more important was the aesthetic battle over the control of colors, signs, symbols, and visual vocabulary. For the Communists, artistic images served as an effective propaganda measure, especially in a vast land with an overwhelmingly illiterate, rural population. This environment enabled the Party to use oil paintings as a way to establish its dominant interpretation of China's past and to present a master narrative of its history.

\footnotetext{
${ }^{4}$ Jin Shangyi, with the help of Cao Wenhan, Wo de youhua zhi lu (My life as an oil painter) (Changchun: Jilin meishu chubanshe, 2000), 62-64. Interviews with Jin Shangyi, 4 Aug. 2004, and 7 Jan. 2006, Beijing.

${ }^{5}$ Matthew Cullerne Bown, Art under Stalin (New York: Holmes \& Meier, 1991), 140, 214.
} 
The use of oil paintings as a political tool is apparent at various times in the history of art. Velázquez's portraits of Philip IV and David's paintings of Napoleon, especially the French artist's rendering of the Bonaparte's coronation, are well-known examples that project the majesty and supreme authority of a monarch to his people. In America, John Trumbull's four murals of the American Revolution, which now grace the Capitol Rotunda in Washington, D.C., affirmed the establishment of a new nation. In the PRC, however, the Communists' use of artworks reached far beyond the mere tension between politics and art to include the influence of the Soviet Union, and the nationalization of oil painting - a medium, after all, introduced from the West. By examining what the Chinese Communists called "revolutionary history painting" (geming lishihua $){ }^{6}$ I will analyze the CCP's propaganda effort to reconstruct an official visual narrative of the nation's history. The analysis focuses on the paintings commissioned by the Museum of the Chinese Revolution (MCR) in the 1950s and early 1960s. Julia Andrews and Kirk Denton have each discussed these paintings, ${ }^{7}$ but few studies have addressed the historical contexts and institutional settings within which these paintings evolved. Nor have these efforts probed deeply the external factors, especially Soviet socialist realism, which had a substantial impact on Chinese oil paintings in the 1950s. This essay explores how the CCP, under the influence of Soviet art and through the Party's various official organizations, especially the Ministry of Culture and the Propaganda Department of the CCP Central Committee, oversaw the choice of historical themes of paintings, selected politically reliable painters, approved the finished products, and ensured that the images were displayed through government-controlled institutions such as museums. I also examine how these paintings were the result of incessant debates and infighting among Party leaders as they tried to produce a politically acceptable history of the CCP.

\section{THE SOVIET INFLUENCE}

Chinese Communists took firm control over art immediately after the founding of the PRC. In contrast, in the Soviet Union paintings with historic themes were not systematically commissioned by the government until the 1930s, and only after the Stalinists had agreed on the history of the Bolshevik Revolution, as published in A Short Course in the History of the All-Union Communist Party (of Bolsheviks) in 1938 (repr. 1940; hereafter Short Course). One of the Chinese government's plans was to suggest a series of history paintings,

\footnotetext{
${ }^{6}$ For the term "revolutionary history paintings" (geming lishihua), see Quan Shanshi, "Cong cuozhe zhong jian guangming" (Seeing the light after adversities), Meishu (Art) 1 (6 Feb. 1962), 50.

7 Julia F. Andrews, Painters and Politics in the People's Republic of China, 1949-1979 (Berkeley: University of California Press, 1994), 75-86, 228-46. Kirk A. Denton, "Visual Memory and the Construction of a Revolutionary Past: Paintings from the Museum of the Chinese Revolution," Modern Chinese Literature and Culture 12, 2 (Fall 2000): 203-35.
} 
especially in oil, to depict the accomplishments of the CCP and its final victory in 1949. In March 1950, with the approval of the CCP's Propaganda Department and Ministry of Culture, a Preparatory Committee for the National Museum of the Revolution (renamed, four months later, the Preparatory Committee for the Central Museum of the Revolution) was set up under the direction of Wang Yeqiu (1909-1987), deputy chief of the Cultural Relics Bureau in the ministry. ${ }^{8}$ In late December 1950, Wang proposed to Vice Minister of Culture Zhou Yang (1908-1989) the mounting of an exhibition on 1 July 1951 to commemorate the thirtieth anniversary of the Party's founding. ${ }^{9}$ The planned exhibit was to include a series of historical paintings and sculptures depicting the Party's history.

Wang Yeqiu's idea of incorporating oil paintings into the exhibition was likely inspired by what he had observed in the Soviet Union. As head of a Chinese delegation to exhibit Chinese art, he made his first official visit to Moscow in October 1950 and was greatly impressed by the art he saw in the city's museums. In the National Museum of the Revolution, for instance, Wang admired how Lenin's political career had been carefully highlighted by artifacts of the revolution, such as newspapers and manuscripts, accompanied by oil paintings and maps. Taken together, according to Wang, the artifacts forcefully chronicled the Bolshevik leader's path of struggle and triumph. Wang wrote admiringly in his report that the items were visually attractive and could be effective educational tools for the public. ${ }^{10}$ His proposal to bring art, especially oil paintings, into the construction of the MCR followed a long-standing Party policy, dating from the Yan'an era, of using art to serve political purposes. It also underscored a fundamental conviction of the Communist leaders that the Party's history should be demonstrated not only by revolutionary artifacts in museums but also through paintings, a move deemed all the more important given the nation's largely illiterate population.

Wang's proposal received preliminary approval in March 1951, when the Art Bureau (Yishuju) of the Ministry of Culture officially approved a plan to realize this task by establishing a Leadership Group of the Production of Revolutionary History Painting (Geming lishihua chuangzuo lingdao xiaozu; hereafter GLCLX). This group was made up of veteran Communist artists such as the cartoonist Cai Ruohong (1910-2002), the art critic Jiang Feng (1910-1982), the sculptor Wang Zhaowen (1909-2004), and the woodcut artist Yan Han (b. 1916). All of them were asked to assemble a team of talented artists to

\footnotetext{
8 Zhongguo geming bowuguan wushinian bianweihui, ed., Zhongguo geming bowuguan wushinian (The fifty years of the Museum of the Chinese Revolution) (Shenzhen: Haitian chubanshe, 2001), 136.

9 Ibid.

10 Wang Yeqiu, "Sulian Guoli geming bowuguan" (Soviet National Revolutionary Museum), Wenwu cankao ziliao (Reference materials on cultural relics) 10 (31 Oct. 1950): 73.
} 
create a series of oil paintings for future museum exhibits. ${ }^{11}$ One person the GLCLX approached was Luo Gongliu (1916-2004), a veteran Yan'an woodcut artist and at the time an instructor at CAFA. Years later, Luo recalled, "In 1951, when the Museum of the Chinese Revolution first commissioned history paintings, they came up with an outline of topics. Yan Han, who coordinated the task, assigned me to work on The Rectification Report (Zhengfeng baogao) (1951, National Museum of China, Beijing). He insisted that it had to be done in oil." 12 Luo finished a painting in which he depicted Mao forcefully delivering his important speeches on thought reform to a group of political and cultural cadres at the CCP's Central Committee headquarters in Yan'an in 1942.

Why was the Party so focused on oil paintings? The GLCLX's decision to commission oil paintings seemed surprising, since in its early years the government was committed to producing accessible, popular art forms, especially nianhua (New Year prints) and lianhuanhua (serial picture stories) to disseminate socialist ideas to the population. ${ }^{13}$ Compared to the New Year prints, the Western medium of oil painting seemed marginal to the government's needs. On closer examination, however, such art had significant value. In the early 1950s both the artistic and the political climate were receptive to oil painting, and the public responded with enthusiasm to the realistic techniques of the genre. Academically, the French-trained Xu Beihong (1895-1953), a renowned oil painter and the director of CAFA, was an advocate of this Western medium. $\mathrm{Xu}$ was one of the most influential artists in China, and noted for his vivid portrayals of galloping horses and his historical paintings, such as his traditional ink work Tian Heng and His Five Hundred Retainers (1928-1930, Xu Beihong Museum, Beijing). Oil painting also received important official endorsement in 1953 when the Party shifted its art policy from popularization to professionalism, with a goal of raising artistic standards by giving young artists systematic and rigorous academic training. The reorganization of art education began in earnest in that same year when CAFA established an oil painting department. This official approval gave the medium proper recognition and an elevated status.

The rising prestige of oil painting also stemmed from the growing influence of Soviet socialist realism, publicly embraced by the Chinese government in the early 1950s when it announced an unequivocal pro-Soviet policy. Socialist realism, promoted by Stalin since the early 1930s, stipulated that art had to be socially relevant to the masses, with all subjects depicted from the viewpoint of the glorious future promised by socialism. Inherent optimism but aesthetic conservatism, along with the interests of the oppressed classes and the ideals

11 Zhongguo geming bowuguan wushinian bianweihui, Zhongguo geming bowuguan wushinian, 137. Interview with Yan Han, 3 Jan. 2006, Beijing.

${ }_{12}$ Liu Xiaochun, Lou Gongliu yishu duihualu, 32.

13 Renmin ribao (People's daily), 27 Nov. 1949: 4. 
of collectivism, were key traits of this Soviet model. ${ }^{14}$ Oil painting was a visual medium well suited to accentuating these traits.

Soviet influence was by no means confined to socialist realism. When, in the early 1950s, American and European art publications were deemed politically degenerate and ceased to be available, imported Soviet magazines became the only venue where art students could get a glimpse of Western art. ${ }^{15}$ Among the Russian oil painters enthusiastically promoted by Chinese art circles were Ilya Repin and Vasily Surikov, two pillars of the Peredvizhniki (Itinerants) school of nineteenth-century Russian painting, whom Xu Beihong had lauded as "two of the greatest painters in the world." 16 Repin and Surikov were renowned not only for their large, sweeping historical canvases but also for their criticism of autocratic rule and their commitment to social commentary (as in Repin's Barge Haulers on the Volga [1870-1873, Russian Museum, St. Petersburg]). This style was in marked contrast to that of the Imperial Academy, which produced neoclassical works on biblical and mythological themes. Stalin's fondness for Repin was well known, and by his direction the Peredvizhniki were resurrected to provide a historical basis for socialist realism, with a stress on art as a vehicle to raise class consciousness. ${ }^{17}$ In China, Repin was praised as a "people's artist," 18 and Surikov was equally honored as a "genius" realist history painter. ${ }^{19}$ Russian artists were not the only ones singled out as models; the French neo-classical painter David was lauded for his realistic portrayal of revolutionary scenes during the French Revolution. ${ }^{20}$ But Russian artists were granted center stage.

For Chinese artists a golden opportunity came in October 1954 when a large-scale exhibition of the Soviet Union's economic and cultural achievements was mounted in the newly constructed Soviet Union Exhibition Hall (now Beijing Exhibition Hall). This major event also displayed key Soviet works in Beijing, including oil paintings such as Boris Ioganson's In an Old Urals Factory (1937, Tretyakov Gallery, Moscow) and Fedor Shurpin's

14 Matthew Cullerne Bown, Socialist Realist Painting (New Haven: Yale University Press, 1998), 131-204; Wolfgang Holz, "Allegory and Iconography in Socialist Realist Painting," in Matthew Cullerne Bown and Brandon Taylor, eds., Art of the Soviets: Painting, Sculpture and Architecture in a One-Party State, 1917-1992 (Manchester, U.K.: Manchester University Press, 1993), 73-85.

15 Interview with Bo Songnian, 6 Aug. 2005, Beijing.

16 Xu Beihong, "Zai Sulian Jieke canguan meishu de jianlüe baogao" (A brief report on art during a visit to the Soviet Union and Czechoslovakia), in, Wang Zhen and Xu Boyang, eds., $X u$ Beihong yishu wenji (Xu Beihong's collected essays on art) (Yinchuan: Ningxia renmin chubanshe, 2001), 546.

17 Bown, Socialist Realist Painting, 187.

18 "Renmin yishujia Yiliya Liebin," (Ilya Repin: The people’s artist); Renmin meishu (People's art) 1, 4 (1 Aug. 1950): 13-14.

19 Chang Nadan, "Xianshi zhuyi de lishi huajia Sulikefu" (Surikov: A realist history painter), Renmin meishu 1, 5 (1 Oct. 1950): 38-40.

${ }^{20}$ Renmin meishu 1, 5 (1 Oct. 1950): 47-49. 
The Morning of Our Motherland (1948, Tretyakov Gallery). ${ }^{21}$ The art show proved memorable and stimulating for young Chinese artists. "This was the first time that I saw the original European oil paintings," recalled Jin Shangyi. $^{22}$

An even more important event was the arrival of Soviet oil painter Konstantin Maksimov in Beijing in February 1955 to offer a class to the students at CAFA. About twenty students were carefully selected nationwide to attend the Soviet master's class. It was the first time a noted Russian painter had appeared before Chinese students to offer professional instruction. ${ }^{23}$ Maksimov was viewed as a skilled practitioner of Soviet socialist realism, as in his painting Sashka the Tractor Driver (1954, Tretyakov Gallery, Moscow), an inspiring image of farm life. "He taught us the basic techniques of sketching as well as the concept of structure (jiegou) in oil painting," his student Jin Shangyi recalled. ${ }^{24}$ His class, commonly known in Chinese art circles as "Maxunban" (Maksimov Training Class), lasted for two years and trained a host of talented young painters, including Jin Shangyi, Hou Yimin (b. 1930), and Zhan Jianjun (b. 1931). Many of them went on to assume key positions in art circles. In the mid-1950s a number of young Chinese artists were also sent by the Chinese government to the famed Repin Institute of Art in Leningrad to learn painting and other techniques, including etching. Among those sent were Luo Gongliu, and Wu Biduan (b. 1926), a young instructor at CAFA. ${ }^{25}$

Ultimately, the rise of oil painting was largely the result of its special appeal as a medium. Its flexibility in the use of colors, its wide range from lights to darks, and its ability to achieve a multiple blending of tones all differed markedly from traditional Chinese ink-and-brush painting, and provided a refreshing alternative to aspiring Chinese artists. "The principal characteristic of oil painting is its realistic touch. Its volume, space, colors, and light are all real. The works are attractive; they draw people's attention," Jin Shangyi recalled in an interview about why he was drawn to this genre as a young artist. ${ }^{26}$ The capacity of oil painting to depict minute details and blend different tones also was ideal, in the words of Cai Ruohong, "in presenting historical themes and delineating heroic personalities."27

21 Renmin ribao, 30 Sept. 1954: 3, 5; Jin Shangyi, Wo de youhua zhi lu, 23.

22 Jin Shangyi, Wo de youhua zhi lu, 23.

23 Jizhe, "Huanyin Sulian youhuajia K. M. Makeximofu" (Welcome Soviet oil painter K. M. Maksimov), Meishu 3 (15 Mar. 1955): 39.

24 Interviews with Jin Shangyi.

25 Interview with Wu Biduan, 30 July 2004, Beijing.

26 Interviews with Jin Shangyi.

27 Cai Ruohong, "Wei chuangzao zui xin zui mei de yishu er fendou" (Striving to create the newest and most beautiful art), Meishu 8-9 (1960): 3 . 


\section{PHASES OF COMMISSION}

Major oil paintings in the Soviet Union were commissioned by official agencies like the Red Army and the People's Commissariat of Heavy Industry. ${ }^{28}$ This became even more frequent after the publication of the authoritative Short Course in 1938, which presented a glowing view of the accomplishments of the Bolsheviks in the Russian Revolution. The establishment of the GLCLX by the Ministry of Culture in 1951 to commission oil paintings for the future MCR bore a close resemblance to the Soviet experience.

The significance of the GLCLX must be understood within the larger context of the CCP's organization and institutional control. From the beginning, Communist leaders considered the future MCR as an important institution to document and showcase the rise and victory of the Party. Therefore, every step of the museum's construction was closely supervised. In fact, institutionally, the GLCLX was the museum's lowest-ranking body to coordinate the commission of art. Above it was the Ministry of Culture, which was directly responsible for the planning and execution of the museum's exhibits. The propaganda department played an even more critical role; as the safekeeper of Party ideology, it oversaw the entire process of construction in terms of policy and displays. To ensure the building's successful completion, in September 1959 the CCP Secretariat set up a still higher-level committee: the Central Leadership Preparatory Committee of the Construction of the Museum of the Chinese Revolution. This Committee was headed by Lu Dingyi (1906-1996), the propaganda chief, and Kang Sheng (1898-1975), a senior member of the Party, and included such powerful officials as Hu Qiaomu (1912-1992), Mao's personal secretary and deputy director of the Propaganda Department, Zhou Yang, another deputy director, and Qian Junrui (1908-1985), the vice-minister of culture. ${ }^{29}$

During the first half of the 1950s the commission's undertakings were limited because for many years the future Museum existed only on the drawing board. Not until August 1958 did the CCP, at a Politburo meeting in Beidaihe, decide to construct, within a year, ten mammoth buildings in the capital to celebrate the tenth anniversary of the 1949 founding of the People's Republic. Among the buildings was the Museum of the Chinese Revolution, which was to have a permanent home in the eastern part of Tiananmen Square. Once the government's decision to build a new museum was clear, the museum planners raced against time to commission new artworks for the opening ceremony in October 1959. But in 1957 Yan Han, the key coordinator in the initial 1951 commission campaign, was purged as a rightist during the Anti-Rightist Campaign. Luo Gongliu was then quickly summoned to

\footnotetext{
28 Bown, Socialist Realist Painting, 136.

29 Zhongguo geming bowuguan wushinian bianweihui, Zhongguo geming bowuguan wushinian, 140.
} 
Beijing from Leningrad and charged with completing the task of commissioning artists for the new museum. With assistance from the influential Cai Ruohong of the Chinese Artists Association, the museum was finally completed, and opened to the public in 1961. ${ }^{30}$

In the eyes of Party officials, three issues had to be addressed regarding how to proceed: Which historical topics should be featured in the oil paintings? Which artists should be commissioned? How should these paintings emphasize Mao's role in Party history, and should the roles played by his key associates be included? By 1951, an official view of the history of the CCP was reached with the publication of Hu Qiaomu's Zhongguo gongchandang de sanshi nian (Thirty years of the Chinese Communist Party). This authoritative text, resembling the Soviets' Short Course, was approved by Mao Zedong and widely distributed. ${ }^{31} \mathrm{Hu}$ based the text on Mao's 1940 influential essay, "On New Democracy," and divided the CCP's history into four periods covering the years 1921 to 1949: the founding of the CCP and the First Revolutionary Civil War (1921-1927); the Second Revolutionary Civil War (1927-1937); the War of Resistance against Japan (1937-1945); and the Third Revolutionary Civil War $(1945-1949) .{ }^{32} \mathrm{Hu}$ thus spelled out an orthodox view of how Party history should be read and interpreted.

Now, with a general guideline of CCP history in hand, the GLCLX initiated several attempts to commission artists to produce works on approved topics. First, politically reliable painters were approached. In the early 1950s the first group of commissioned artists included Dong Xiwen, who joined the CCP in December 1949, Luo Gongliu, and Wang Shikuo (1911-1973), a veteran Party member since 1942. But Communist sympathizers such as $\mathrm{Xu}$ Beihong were also recruited. A second consideration was whether these artists were technically competent to undertake the task. Dong Xiwen was an accomplished painter and a professor at CAFA, and clearly a good candidate. Moreover, because the focus was on historical subjects, those artists who had actually participated in the historical events to be depicted would have an edge. Thus Luo Gongliu's participation in the 1942 Rectification Campaign in Yan'an made him an ideal candidate to paint this important episode in CCP history. This resulted in his famous Rectification Report, mentioned earlier.

Because the projects were widely regarded as, in the words of painters Hou Yimin and Zhan Jianjun, "state assignments" (guojia renwu), those recruited

${ }^{30}$ Liu Xiaochun, Lou Gongliu yishu duihualu, 92-94.

31 Ye Yonglie, Hu Qiaomu (Hu Qiaomu). (Beijing: Zhonggong zhongyang dangxiao chubanshe, 1994), 3, 104-6.

$32 \mathrm{Hu}$ Qiaomu, Zhongguo gongchandang de sanshi nian (Thirty years of the Chinese Communist Party) (Beijing: Renmin chubanshe, 1951). 
felt "extremely honored," 33 no doubt appreciating, too, the added benefit of garnering nationwide visibility. In my recent interviews with the participating artists, almost half-a-century later, many still evinced pride and enthusiasm for this important mission. ${ }^{34}$ Officials facilitated the project by providing the artists with all sorts of support, including on-site visits, and encouraged them to conduct historical research, examine old photos, read memoirs, dig up archival materials, and interview eyewitnesses to arrive at a faithful rendition of their chosen subjects. $^{35}$ In 1961 the government also furnished artists food and lodging, arranging stays at the Oriental Hotel (Dongfang fandian) to paint their works. "We were well housed and better fed at a time of great turmoil after the Great Leap Forward when food was scarce and supplies woefully limited," said Zhan Jianjun. ${ }^{36}$ The artists' sense of involvement was strong, and many perceived this as a rare opportunity to help create a new nation through their artistic skills. Indeed, the artists were enthusiastic in joining the chorus of those who wished to build a new socialist state in China. They played a role in establishing, not simply conforming to, the Maoist view of history.

The third issue - the proper assessment of Mao's role in Party history — was a much thornier subject. In fact, the reason the scheduled opening of the MCR on the 1 October tenth anniversary did not materialize was that senior Party members disputed Mao's centrality: Should the chairman's contributions be singularly highlighted in the museum, or should his achievements be paired with other senior leaders such as Liu Shaoqi and Zhou Enlai? These debates, known at the time as the issue of the "Red Line," meaning the proper historical role of Mao's leadership, led to many rounds of preliminary exhibits held at the MCR. ${ }^{37}$ Among senior leaders, Kang Sheng took the extreme position that Mao's preeminence must be singularly highlighted, whereas Zhou Yang proposed a more balanced treatment of the Party's history, with reasonable coverage of the achievements of other senior leaders. ${ }^{38}$ When the museum officially opened in July 1961 an approach closer to Zhou Yang's view was adopted, although Mao was still depicted as being head-and-shoulders above his closest associates.

The Red Line was not the only issue that troubled the artists. A more immediate concern was that of the themes of the visual representations. In the 1950s, Chinese art was under the strong sway of Soviet socialist realism, which, in addition to its obligatory optimism, stressed "thematic art," a term

33 Hou Yimin, "Wo he wo de geming lishihua," (I, the artist, and my revolutionary history paintings), Meishu bolan (Art review) 17 (25 June 2005): 33. Interview with Zhan Jianjun, 2 Aug. 2005, Beijing.

34 Interviews with Hou Yimin, 1 Aug. 2004 and 9 Jan. 2006, Beijing; interview with Zhan Jianjun; interviews with Jin Shangyi.

35 Interview with Zhan Jianjun.

36 Ibid.

37 Chang-tai Hung, “The Red Line: Creating a Museum of the Chinese Revolution," The China Quarterly 184 (Dec. 2005): 914-33.

38 Ibid. 


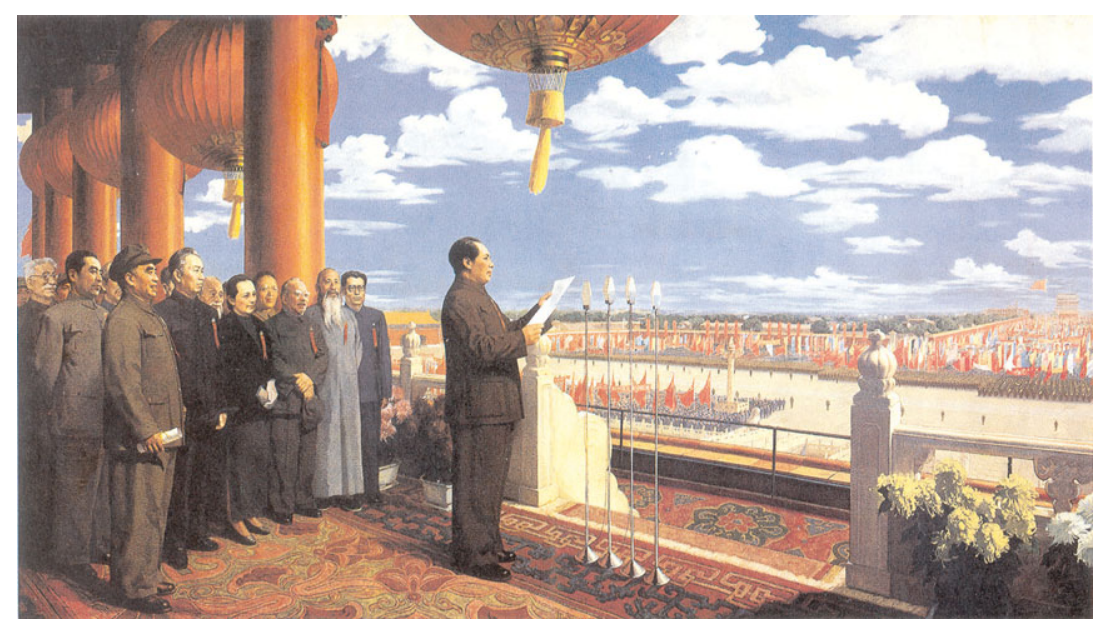

Figure 1 Reproduction by Jin Shangyi, Zhao Yu, and Yan Zhenduo of Dong Xiwen, The Founding Ceremony of the Nation, ca. 1979, oil on canvas, $230 \times 405 \mathrm{~cm}$. National Museum of China (formerly Museum of the Chinese Revolution), Beijing.

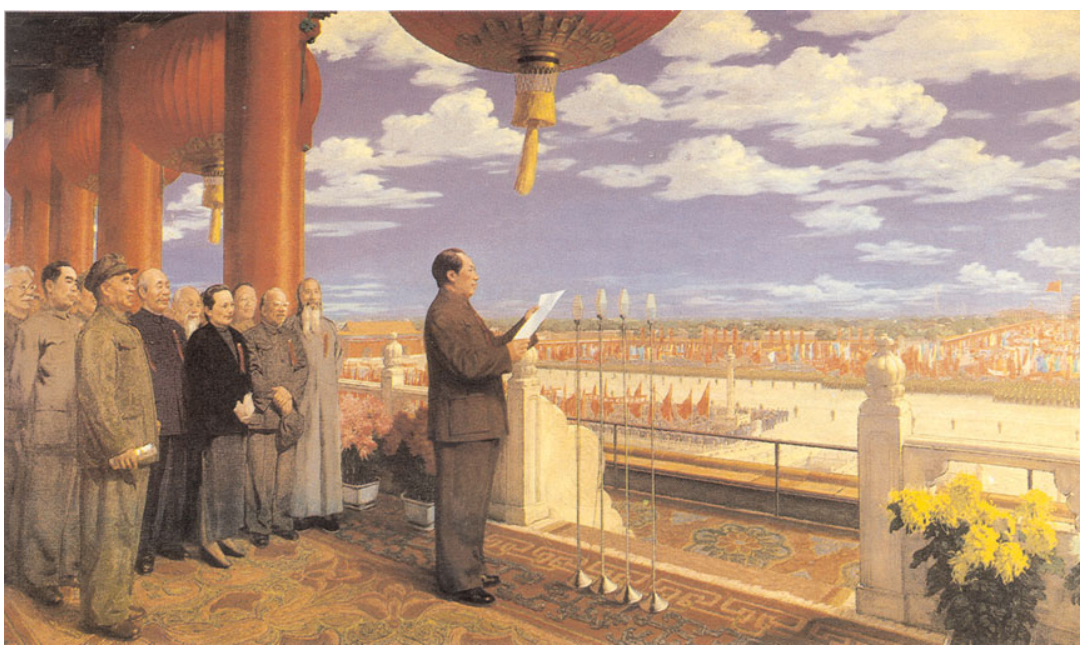

FIgURE 2 Dong Xiwen, The Founding Ceremony of the Nation, ca. 1967, oil on canvas, $230 \times$ $405 \mathrm{~cm}$, National Museum of China, Beijing. 


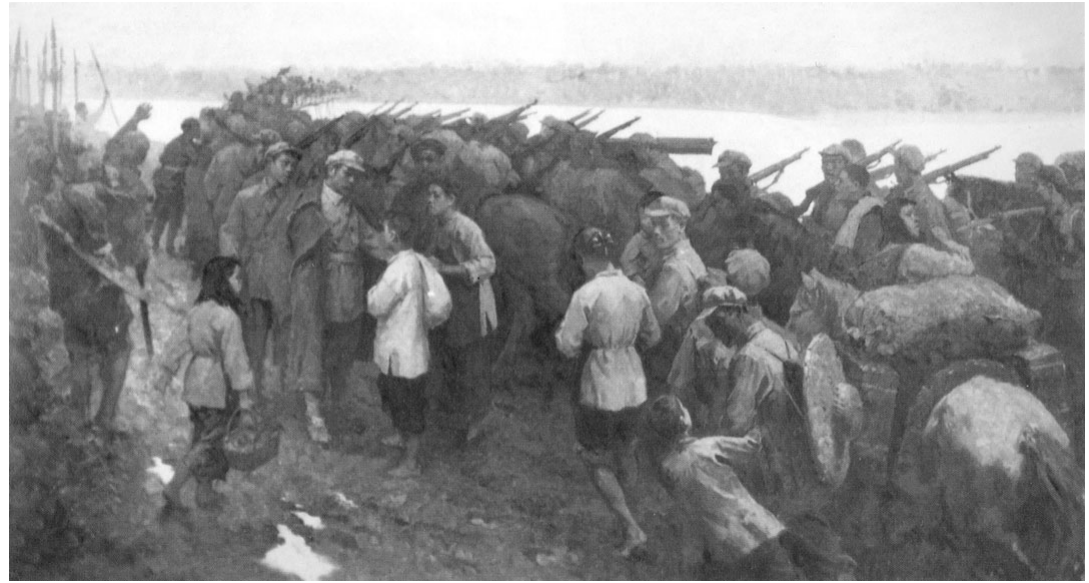

Figure 3 Jin Shangyi, Farewell, 1959, oil on canvas, $137 \times 242 \mathrm{~cm}$. National Museum of China, Beijing. 


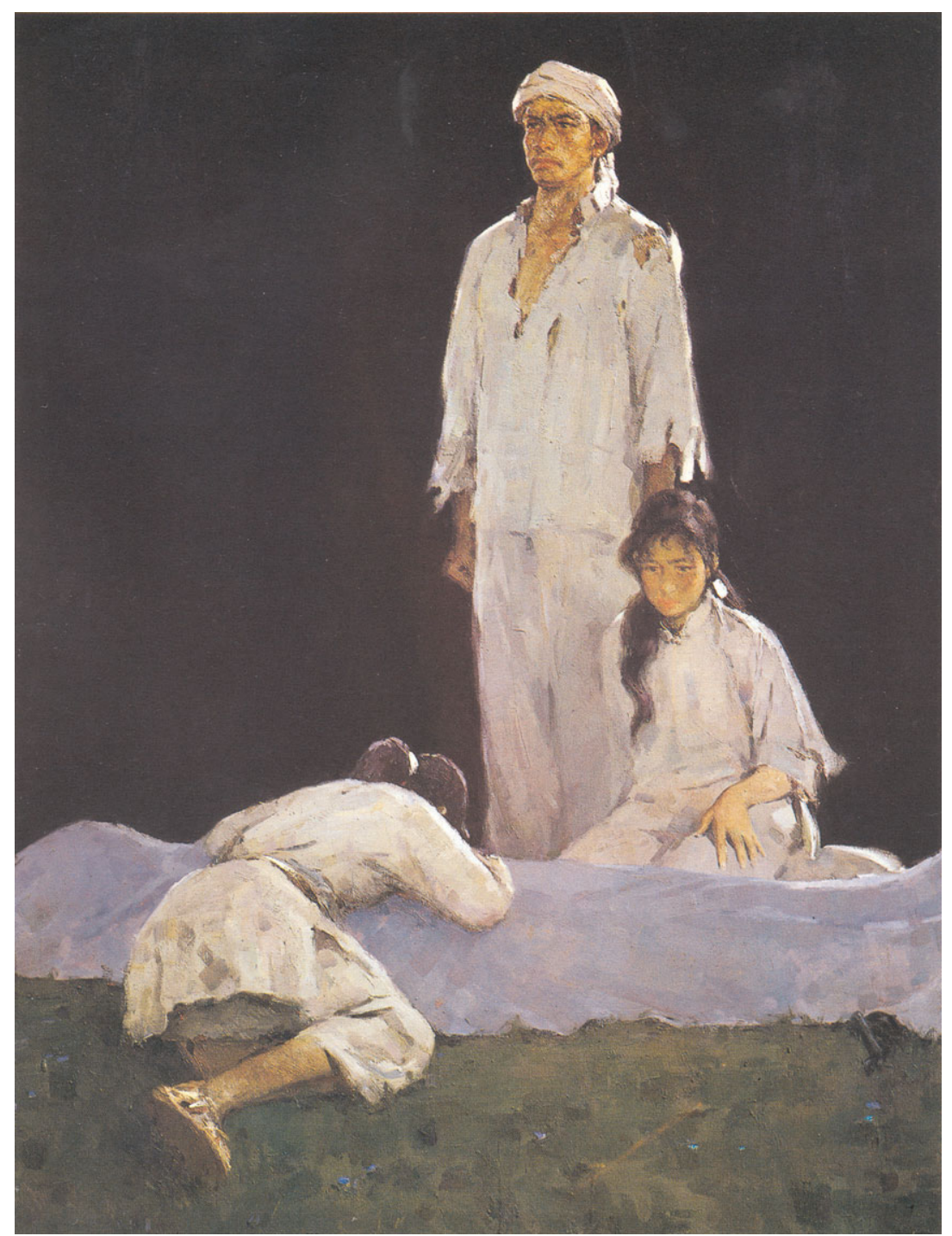

Figure 4 Luo Gongliu, Behind the Fallen Are Endless Successors, 1959, oil on canvas, $181 \times$ $152 \mathrm{~cm}$. National Museum of China, Beijing. 


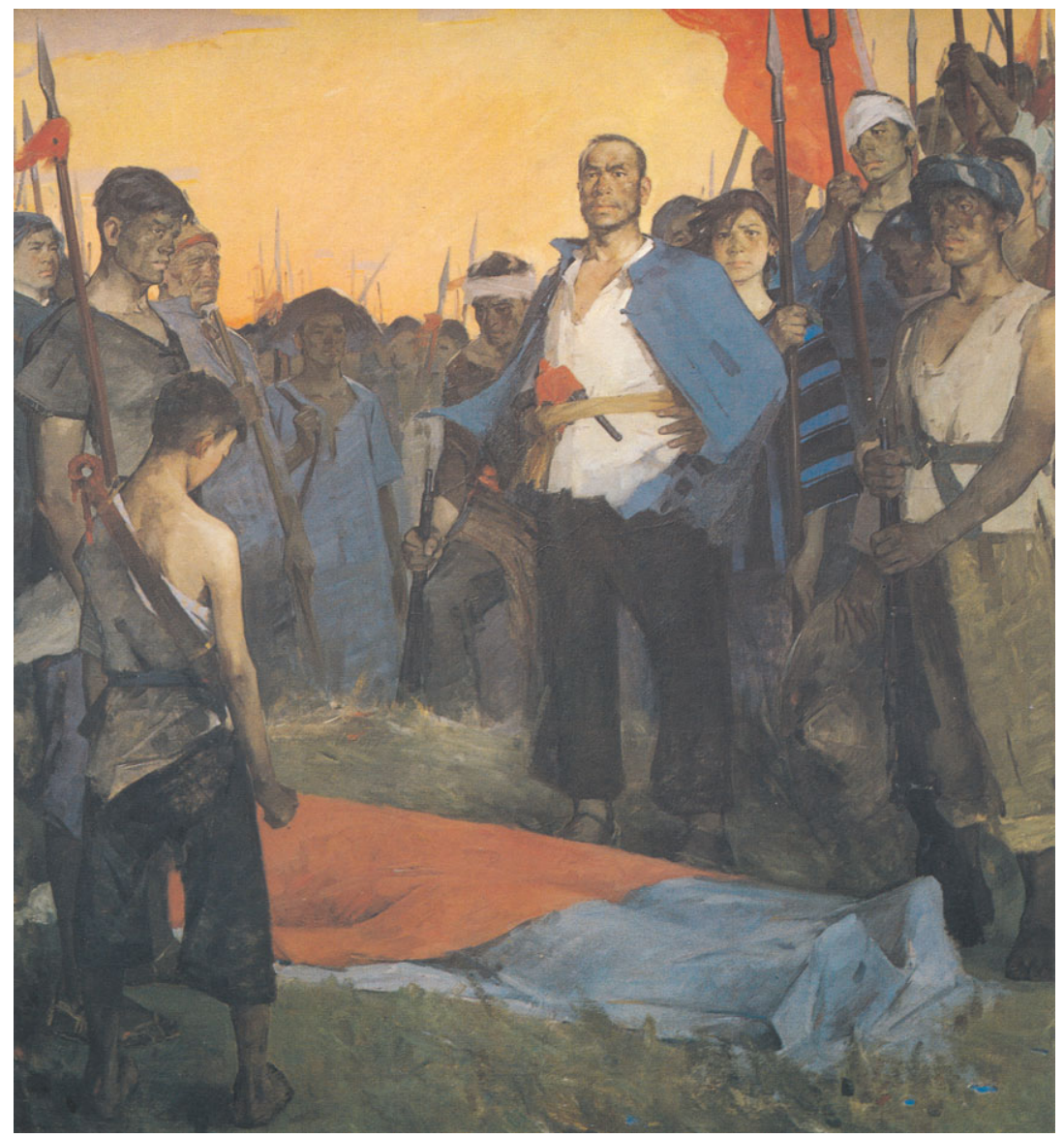

Figure 5 Quan Shanshi, Unyielding Heroism, 1961, oil on canvas, $233 \times 217 \mathrm{~cm}$. National Museum of China, Beijing. 


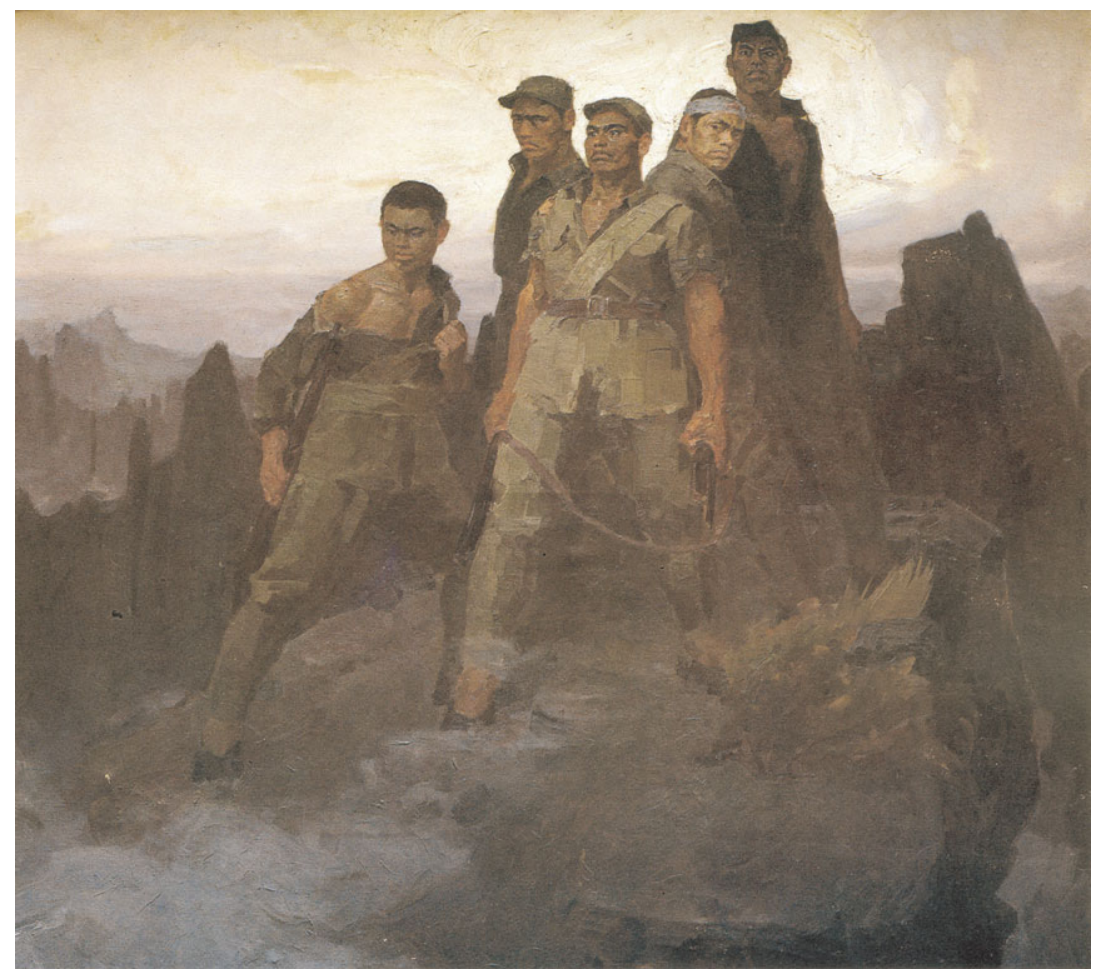

Figure 6 Zhan Jianjun, Five Heroes of Mount Langya, 1959, oil on canvas, $185 \times 203 \mathrm{~cm}$. National Museum of China, Beijing. 


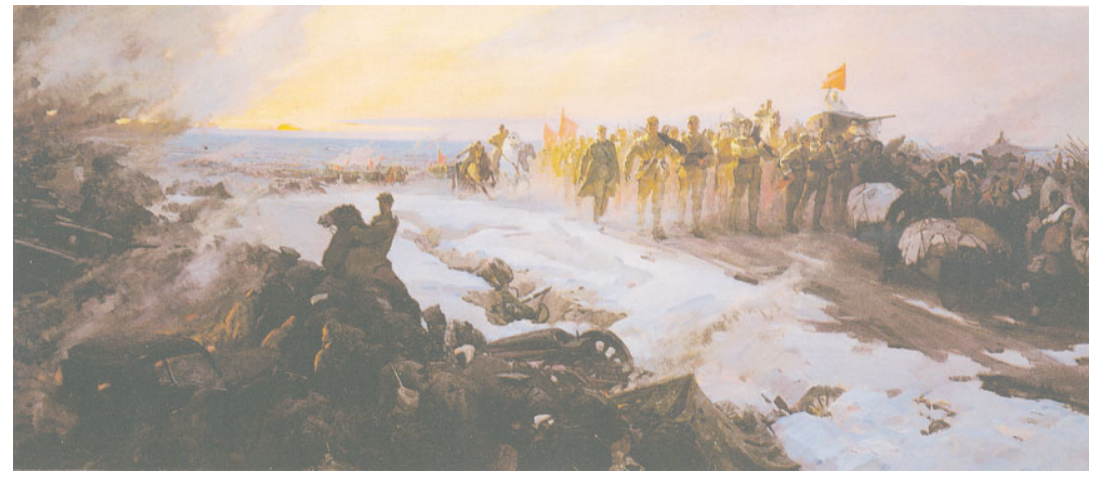

FIgURE 7 Bao Jia and Zhang Fagen, A Great Victory in Huai-Hai, 1959, oil on canvas, $150 \times$ $320 \mathrm{~cm}$. National Museum of China, Beijing. 


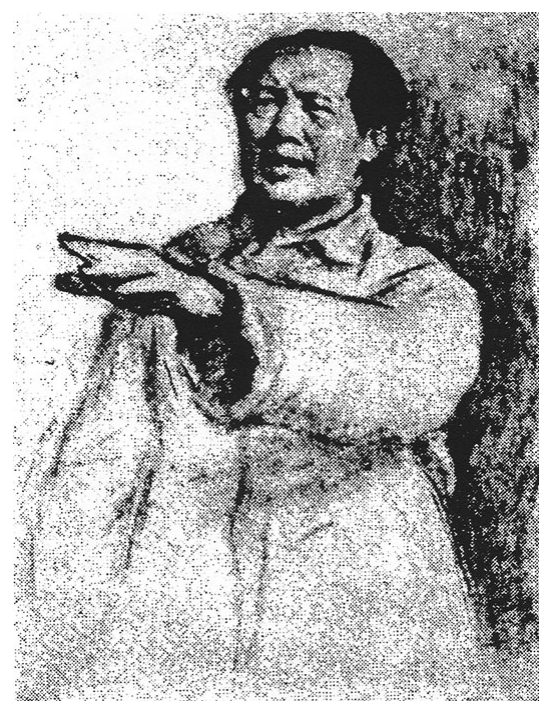

FIgURE 8 Jin Shangyi, preliminary study for Chairman Mao at the December Conference, ca. 1961. Jin Shangyi, "Chuangzuo Mao zhuxi zai shieryue huiyi shang de tihui" (My reflections on painting Chairman Mao at the December Conference), in Geming lishihua chuangzuo jingyan tan (On the creation of revolutionary history paintings) (Beijing: Renmin meishu chubanshe, 1963), 41.

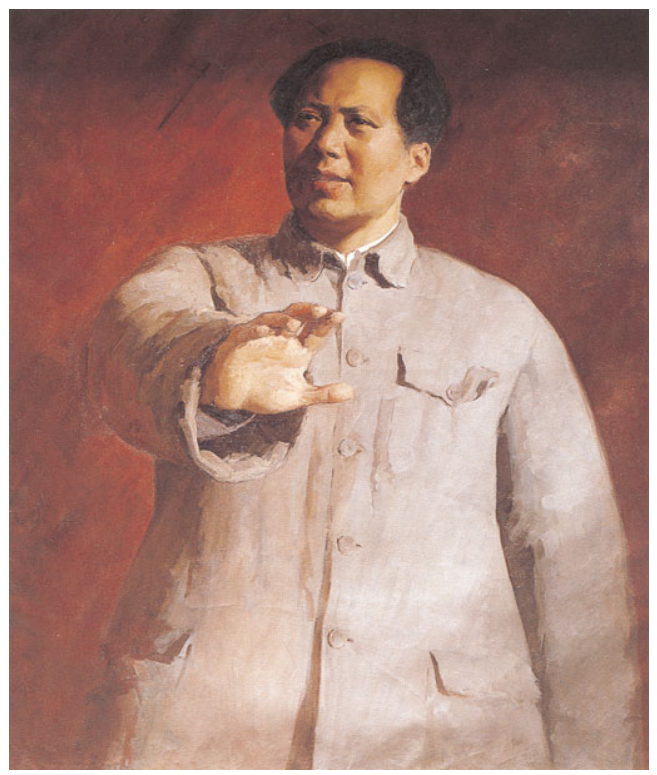

Figure 9 Jin Shangyi, Chairman Mao at the December Conference, 1961, oil on canvas, $158 \times$ $134 \mathrm{~cm}$. National Museum of China, Beijing. 


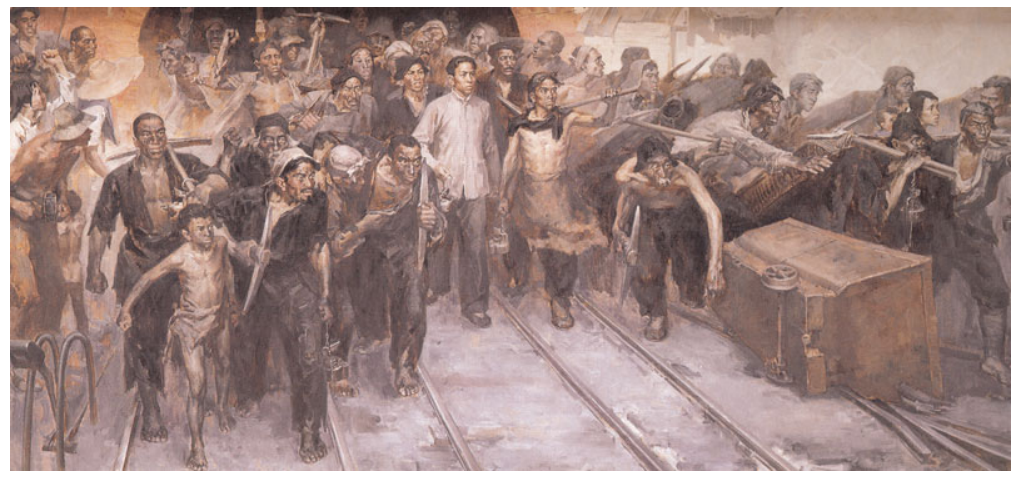

Figure 10 Hou Yimin, Comrade Liu Shaoqi and the Anyuan Coal Miners, 1961, oil on canvas, $160 \times 330 \mathrm{~cm}$. National Museum of China, Beijing. 
that, according to Igor Golomstock, in Soviet aesthetics means "the depiction of the leadership and their colleagues, revolutionary events, heroics in work and war." 39 Chinese artists followed suit. They were asked to emphasize historic themes (zhuti), thus underscoring "representativeness" (dianxinghua) of these themes in their works; ${ }^{40}$ that is, they were required to capture a unique historical moment not only with a high degree of accuracy but also with a particular focus. Cai Ruohong explained this official line when he wrote that historical themes must exhibit two major characteristics: they must "reflect the revolutionary movement of workers, peasants, and soldiers and their revolutionary wars [against imperialism and capitalism], and portray the determination and integrity of revolutionary heroes."41 But it was never easy to implement these ideas on canvas.

Between 1958 and 1961 senior officials carried out many rounds of internal investigations to arrive at an acceptable chronicle of Party history. Although we have no inventory of how many paintings were actually produced - museum archives remain closed to outsiders - we do know that many were deemed questionable and abandoned. ${ }^{42}$ The rejected artwork tells us as much about the Party's views as do those that were eventually approved.

Jin Shangyi's Farewell (Songbie) (Figure 3) was one of the rejected pieces. A gifted student of Maksimov, Jin, like others, was sent to on-site visits in Jiangxi in 1959 to work on a piece about the legendary Long March. ${ }^{43}$ Inspired by a popular song, "Ten Farewells to the Red Army" (Shisong Hongjun), which describes the pain of separation between soldiers and their families and fellow villagers at the start of the Long March in late 1934, Jin painted the Red Army's departure with a great deal of emotion. Soldiers in the painting leave at dawn, against a gray sky; their teary wives watch them depart; parents with heavy hearts bid their sons farewell-the entire scene exudes the sadness of separation. "Mine is a realistic portrayal of the difficulty of parting," Jin declared in an interview. ${ }^{45}$ "I wanted to uphold the idea of a strategic military shift, but I also knew that I could not portray despondency. Overall I think the entire piece is upbeat." 46 But this was not what some Party leaders saw in the painting. During an inspection of the exhibits, Kang Sheng criticized Jin's Farewell as too gloomy. In his view, the painting

\footnotetext{
39 Igor Golomstock, "Problems in the Study of Stalinist Culture," in, Hans Günther, ed., The Culture of the Stalin Period (New York: St. Martin's, 1990), 114.

40 Zhu Di, "Tan lishi ticai de meishu chuangzuo" (On historical topics in art) Meishu 3 (6 June 1961): 41 .

${ }^{41}$ Cai Ruohong, "Wei chuangzao zui xin zui mei de yishu er fendou," 5.

42 Although a full inventory of the oil paintings is not available, some journals printed photographs of the exhibition. See Wenwu (Cultural relics) 7 (July 1961).

43 Jin Shangyi, Wo de youhua zhi lu, 48. Interviews with Jin Shangyi.

44 Jin Shangyi, Wo de youhua zhi lu, 49-50.

45 Interviews with Jin Shangyi.

46 Jin Shangyi, Wo de youhua zhi lu, 49.
} 
"does not fully demonstrate the Red Line of Mao Zedong thought"; 47 that is, the despondent mood in Jin's work contradicted revolutionary optimism, an essential requirement of socialist realism.

Coordinator Luo Gongliu ran into trouble himself. In 1959 he unveiled a painting, Behind the Fallen Are Endless Successors (Qianpu houji) (Figure 4), depicting the sacrifice of the revolutionaries during the Guomindang's purge of the Communists in 1927. A martyr's body lies on the floor beneath a cloth, surrounded by three grieving family members - two girls and one young man-all in white mourning clothes. The young man, standing tall and gazing into the distance, appears defiant and determined. A dark background conveys a sense of terrible loss. Influenced by Rembrandt, Luo was unique among his peers in his skill at rendering light and shade in his works. $^{48}$ By contrasting the white apparel with the sober setting and using the living and dead to form a reverse " $\mathrm{T}$ " shape, Luo presents in his painting what one art critic calls a memorable "jade monument" (yubei), one that symbolizes the selfless sacrifice of the Communists. ${ }^{49}$ The painting's original title, The Seed of Fire (Huozhong), evokes a similar hope for the future. ${ }^{50}$ But, like Jin's Farewell, Luo's painting was criticized for its serious deviation from the approved aesthetic vocabulary, that is, for "portraying too miserable a scene," and therefore his picture was removed. ${ }^{51}$

\section{THE APPROVED}

When the Museum of the Chinese Revolution received official authorization to open its doors on 1 July 1961, all of its approved commissioned paintings, in addition to the revolutionary artifacts, were finally on view. But the MCR was not the only institution to commission oil paintings in the $1950 \mathrm{~s}$, as others such as the Chinese Military Museum followed suit. Moreover, in addition to oil paintings, the Party sought other art forms to document its history. Among the best known were Wang Shikuo's Bloodstained Garment (Xueyi) (1959, National Museum of China, Beijing), a black-and-white charcoal drawing about peasants during land reform testifying against landlord brutalities. Shi Lu's (1919-1982) Shifting Military Strategy in Northern Shaanxi (Zhuan zhan Shaanbei) (1959, National Museum of China, Beijing), a traditional Chinese ink painting, depicts Mao's military maneuver when the Nationalist forces attacked Yan'an in

\footnotetext{
47 Ibid.

48 Luo acknowledged Rembrandt's influence on his paintings. See Liu Xiaochun, Luo Gongliu yishu duihualu, 54.

49 Liu Xiaochun, "Luo Gongliu,” Jujiang meishu zhoukan: Zhongguo xilie (Masters of Chinese painting) 111 (12 Oct. 1996): 8. See also Liu Xiaochun, Luo Gongliu yishu duihualu, 130-33.

${ }^{50}$ Liu Xiaochun, Luo Gongliu yishu duihualu, 125.

51 Ibid., 126.
} 
1947. Gu Yuan's (1919-1996) Liu Zhidan and the Red Brigades (Liu Zhidan he chiwei duiyuan) (1957, National Museum of China, Beijing) is a woodcut of an early Communist leader in Shaanxi Province. Still, few media matched the emotions elicited by oil paintings. An examination of these paintings reveals the emergence of various themes; the most prominent being the martyr, the military, the leader, the worker, and the founding of the new nation.

\section{The Martyr}

An icon in Chinese Communist oil paintings was the image of a fallen comrade, and one of the most celebrated works on this topic, an example of Soviet socialist realism, was Quan Shanshi's (b. 1930) Unyielding Heroism (Yingyong buqu; 1961) (Figure 5). Quan, an oil painter who had studied at the Repin Institute of Art in Leningrad, claimed to have been inspired by Mao's influential 1945 essay "On Coalition Government," in which the chairman wrote about the "White Terror" unleashed by the Nationalists to annihilate the Communists in April 1927. In that essay Mao wrote, "The Chinese Communist Party and the Chinese people were neither cowed nor conquered nor exterminated. They picked themselves up, wiped off the blood, buried their fallen comrades, and went into battle again." 52

Quan's painting depicts the body of a martyr lying in a lush field and covered by a red cloth, an indication of his revolutionary spirit. Surrounding the body are peasants who look both indignant and defiant, many of them having been wounded in the battle. In their hands are long spears, pitchforks, and guns in preparation for the next skirmish to defend their territories. Red banners, signifying the group's political nature, flutter in the background. In the middle stands a leader, hands on hips, his gaze reflecting the glorious future made possible only by the sacrifice of such martyrs. Others mourn silently. In the foreground, a young boy, fists clenched, a sword strapped to his back, stands before the fallen martyr to pay his respects. While the group appears to display extraordinary restraint, their postures portray fierce resistance and a readiness for self-sacrifice. The individuals in the painting reflect a new realism in art that differed markedly from traditional Chinese painting in which artists emphasized the inner lives of individuals, and not their formal appearance, by means of their surroundings and various attributes.

Andrei Sinyavsky, in his noted essay "On Socialist Realism," contends that a basic quality of socialist realism is the image of self-sacrifice, one that artists used to raise the heroes of socialism "ever higher and higher on the ladder of

52 Quan Shanshi, "Cong cuozhe zhong jian guangming," 48. Mao Zedong, "On Coalition Government," in Selected Works of Mao Tse-tung, 5 vols. (Peking: Foreign Languages Press, 19671977), 3: 211. 
political morality." 53 Clearly Quan Shanshi intended to honor this noble spirit by monumentalizing the martyrs. In his words: "To enhance the symbolic representation of my painting, I monumentalize martyrs as a way to express the people's grief and hatred, as well as their confidence in their strength to endure future struggles." 54 Displaying the martyr's body, Quan affirmed, "is critical to the entire setting of the painting .... Without that, the painting does not achieve the intended effect." a symbol of the future, conveys, according to the artist, "the idea of the continuing struggle [for the revolution]." ${ }^{, 56}$ The sun's first glow as it rises in the background announces the dawning of a new era.

The design of the painting, ironically, resembles that of Luo Gongliu's rejected piece, Behind the Fallen Are Endless Successors. But the reason Quan's piece was endorsed and Luo's rejected was that, for the inspectors, the two paintings reflect a very different spirit: whereas the latter appeared pessimistic, the former captured the promise of a successful Communist revolution.

\section{The Military}

Another central theme in socialist art was the portrayal of the great battles in the history of the CCP. One such theme was reflected in paintings that glorified the Red Army's military tradition and justified the continuing armed struggle against the enemy. Two military topics addressed by such paintings were the War of Resistance against Japan (1937-1945), exemplified by Zhan Jianjun's Five Heroes of Mount Langya (Langyashan wu zhuangshi; 1959), and the civil war against the Nationalists, depicted in Bao Jia's (b. 1933) and Zhang Fagen's (b. 1930) Great Victory in Huai-Hai (Huai-Hai dajie; 1961).

Zhan Jianjun's Five Heroes of Mount Langya (Figure 6) combines careful research and superb craftsmanship. Based on a true story, the painting portrays five Communist soldiers who fought against Japanese troops at Mount Langya in Yi County, Hebei Province, in September 1941. Refusing to surrender when their ammunition ran out, they jumped off the cliff to demonstrate their unyielding spirit, but two eventually were rescued. Like other commissioned artists, Zhan Jianjun researched the event he would portray; he visited the original site and interviewed the two survivors to acquire a sense of historical accuracy and to imagine the trauma of loss.

53 Abram Tertz, On Socialist Realism, intro. by Czeslaw Milosz (New York: Pantheon, 1960), 48.

${ }_{54}^{54}$ Quan Shanshi, "Cong cuozhe zhong jian guangming," 49.

55 Ibid., 50 .

56 Ibid. 
The artist's portrayal of the scene was imaginative. Instead of depicting conventional combat, Zhan painted five heroes with guns in their hands standing atop a cliff preparing to jump. "To create a memorable effect I wanted to capture the soldiers' indomitable spirit just before their sacrifice," Zhan wrote in an article soon after he had completed the painting. ${ }^{57}$ Zhan's painting stresses the coherence of the group, but their distinct expressions also highlight their individuality. The human pyramid shaped by the five soldiers reflects the artist's long-standing interest in geometric form, an element highlighting many of his works. This pyramidal arrangement is also seen in the ordering of the mountain ranges in the background upper right, which conveys a kind of solemnity for those viewing the scene from below. The pyramidal design, in the words of the artist, was intended "to create the effect of a monument." 58 Zhan's efforts were clearly successful, as one art critic commented: "The soldiers appear not to be standing on the top of a hill but to be growing out of it." 59

Bao Jia's and Zhang Fagen's Great Victory in Huai-Hai (Figure 7) illustrates a different type of military conflict: it is a panoramic view of the Red Army on its invincible march in central China during the civil war between the Communists and the Nationalists (1945-1949). Painted in the customary horizontal format in oil history painting, A Great Victory in Huai-Hai shows the Communists' victorious conclusion of the Huai-Hai campaign that was waged in southern Shandong and northern Jiangsu from late 1948 to early 1949. With red flags waving and tanks rolling, countless soldiers, some on horseback but most on foot, move in a grand procession across the battlefield. Following them on the right, at the upper part of the painting, are the commoners pushing carts carrying their belongings, forming a bond between commoners and soldiers. Relegated to the lower left of the painting are wounded Kuomintang soldiers and what remains of their damaged trucks. Thus the design of the painting marks a clear diagonal division between the victors and the defeated. The contrasting colors are sharp and distinctive. At the upper section of the painting the PLA marches under a bright, dawning sky, the sign of a promising future, whereas the vanquished are depicted in blue and dark colors, reflecting derision and defeat. The color variation in the painting, both "bright versus dark, cold versus warm," Bao Jia explained, were intended to reflect "the power of the people's revolutionary forces surging ahead with great momentum.",60

57 Zhan Jianjun, “Zou wanlu yougan” (Reflections on taking a roundabout course), Meishu 6 (6 Dec. 1961): 31 .

58 Ibid.

59 Zhu Di, "Guangming zai qian” (The future is bright), Meishu 4 (6 Aug. 1961): 26.

60 Bao Jia, "Cong zhanzheng da changmian zhong biaoxian shidai jingshen" (Expressing the spirit of the time through great war scenes), Meishu 6 (6 Dec. 1961): 30 . 
Soviet military canvases often depict two principal features of war - the confrontation of adversaries and the prospect of violent death-as in Aleksandr Deineka's Defense of Sebastopol (1942, Russian Museum, St. Petersburg). This is not the case in Chinese revolutionary history paintings. A Great Victory in Huai-Hai pictures neither the mayhem nor madness of real battle. Instead, it portrays a strong political message: the outcome of the campaign is assured and the socialist future is bright. The marching troops are intended to show, in the words of Bao Jia, that the Communists "will carry the revolution through to the very end." 61

\section{The Leader}

At the heart of socialist realism is the subject of the supreme leader, an image clearly evident in the Soviet Union in the 1930s and 1940s when portraits of Stalin occupied center stage in the government's visual propaganda. The same can be said of China, where Mao's dominance was unparalleled. Nowhere was this shown more visibly than in Jin Shangyi's Chairman Mao at the December Conference (Mao zhuxi zai shieryue huiyi shang; 1961) (Figures 8 and 9).

Jin Shangyi's painting, a tribute to Mao's leadership, portrays the chairman's role in a crucial conference of the CCP Central Committee held in Mizhi, Shaanxi Province, in December 1947, which charted a new course of the Party in China's civil war against the Nationalists. The new direction spelled out by Mao in his famous report, "The Present Situation and Our Tasks," was to destroy Chiang Kai-shek and, in Mao's words, send the Nationalists "down the road to destruction" as well as to "establish a democratic coalition government." Mao then concluded, "The dawn is ahead, we must exert ourselves." $" 62$

When Jin was assigned to capture this historic meeting on canvas, he was keenly aware of what was expected of him. His mission, in his own words, was to demonstrate the chairman's 'brilliance, wisdom, determination, steadfastness, foresight, and ability to anticipate the imminent victory of the nationwide revolution" at a critical junction in CCP history. But unlike Aleksandr Gerasimov, the Soviet court painter who had personally met Stalin and painted a number of the Soviet leader's portraits, including the famous Stalin and Voroshilov in the Kremlin (1938, Tretyakov Gallery, Moscow), Jin had never met Mao and had to rely on "photos and documentaries, as well as descriptions from those who had seen him." 63 Jin realized that when portraying

${ }^{61}$ Ibid.

${ }^{62}$ Mao Zedong, "The Present Situation and Our Tasks," in Selected Works of Mao Tse-tung, 4: 157, 169, 173.

63 Jin Shangyi, "Chuangzuo Mao zhuxi zai shieryue huiyi shang de tihui" (My reflections on painting Chairman Mao at the December Conference), Meishu 6 (6 Dec. 1961): 10-11. 
a towering figure like Mao, he was required not just to arrive at an acceptable likeness but to create an icon. He first worked on Mao's hands, believing that they spoke with the same eloquence as the leader's facial appearance. "Without a forceful hand gesture," Jin told us, "it would be difficult to demonstrate the chairman's bold vision in brilliantly arriving at correct decisions." With a huge frame dominating the entire picture, the final work shows a confident leader forcefully extending his right arm to deliver a point. Mao's facial expression is one of certainty and decisiveness, bespeaking total control of any situation. Mao is speaking to his senior associates at the meeting, but they are not shown in the painting. By leaving out the audience, Jin Shangyi generates tension between the chairman and his followers, and provokes the viewer's curiosity regarding the expressions on his listeners' faces, which can only be imagined.

The chairman is viewed from below to make him appear taller and more majestic. His posture suggests demonstrative authority, underscoring his masterful command of the situation. The original background was a white wall, but Jin made it dark red, not only to produce a sharper visual contrast with Mao's gray dress but also, in the artist's words, "to present a revolutionary flavor," 64 as red was the revolutionary color. The singular focus on Mao speaks loudly of the chairman's unparalleled position in the Party. It also conveys the sanguine view that he will lead the country to a bright future. Jin's piece was clearly influenced by Soviet art. Like his teacher Maksimov, Jin is a distinguished portrait artist who captures the leader's imposing character with great sensitivity. His conception of the hand gesture may have been influenced by his Soviet counterparts, who often portrayed Lenin and Stalin with their arms raised, presumably pointing toward the future, as in Vladimir Serov's Lenin Declares Soviet Power (1947, Tretyakov Gallery, Moscow) ${ }^{65}$ and Viktor Tsyplakov's V. I. Lenin (1947, Historical Museum, Moscow).

\section{The Worker}

Whereas Jin Shangyi's Chairman Mao at the December Conference focuses on Mao, the painting Comrade Liu Shaoqi and the Anyuan Coal Miners (Liu Shaoqi tongzhi he Anyuan kuanggong; 1961) (Figure 10), by Hou Yimin, another student of Maksimov's, tells the story of another Communist leader in a different kind of struggle: the role played by Liu Shaoqi (1898-1969) in a coal miners' strike against an exploitative social system in Anyuan, Jiangxi Province, in September 1922.

\footnotetext{
64 Interviews with Jin Shangyi.

65 A replica of Serov's painting was sent as a gift by the Soviet Union and displayed in the same museum in 1961. Wenwu 7 (July 1961): n.p. (photo).
} 
In Marxist rhetoric, workers play a most critical role in forging a socialist revolution. They were credited as the chosen people who brought the Bolsheviks to power. Sanctification of the proletariat had long been exploited by Soviet painters, as in the case of Boris Ioganson's famous In an Old Urals Factory, which depicts grim working conditions and the awakening of class consciousness among the proletariats. Ioganson's piece was one of the most influential among young Chinese artists in the $1950 \mathrm{~s},{ }^{66}$ but whereas the Russian artist's work dwelt only on the gathering storm between the two opposing classes, Hou's Comrade Liu Shaoqi and the Anyuan Coal Miners describes an organized strike in full action.

To help give his painting a realistic touch, Hou visited Anyuan twice. He wanted to faithfully portray this pivotal event in the history of the CCP. ${ }^{67}$ In Hou's painting, Liu Shaoqi is a young labor leader directing the fight against the exploiters, an episode officially canonized in the 1950s as an early attempt by the CCP to launch the trade union movement in the country. How would Liu Shaoqi as a leader be portrayed on canvas? Early on, Hou confessed that he had difficulty with the painting in juxtaposing Liu as "one of the workers" as well as the organizer of the strike expressing "determination and farsightedness."68 But the finished product reveals no such conflict. Liu is clearly the leader directing a multitude of workers advancing along the road to demolish an unjust system. Situated at the top of the triangular design of the painting, he radiates an unstoppable energy. But the strike is never a solitary struggle - with arms raised in protest and pickaxes on their shoulders, the workers "are on the offensive," as one art critic described this combative scene. $^{69}$

To add a more realistic touch, Hou arms the miners with lamps and winnowing baskets, along with their pickaxes. The miners are not undifferentiated followers of a charismatic organizer, nor are they a faceless crowd. The artist's depiction of distinct personalities is a unique feature of the painting. Many workers were modeled after real people, the artist pointed out. The wounded worker on the left of Liu was modeled after Zhou Huide, a worker who died as a martyr in a subsequent labor strike. On the right is a white-bearded old man, whose crooked back is the result of lifelong hardship under an oppressive mining system. But now, with pickaxe in hand, he is fighting back. Moreover, a child laborer, placed at the front on the left, symbolizes both the cruelty of the child labor system and a successor to the revolution. The child's clothes are tattered, but he wears a red necklace, a local emblem of longevity, thus adding a local

66 Jin Shangyi, Wo de youhua zhi lu, 131. Interviews with Hou Yimin.

67 Interviews with Hou Yimin.

${ }^{68}$ Hou Yimin, "Liu Shaoqi tongzhi he Anyuan kuanggong de gousi” (My conception of the painting Comrade Liu Shaoqi and the Anyuan Coal Miners), Meishu 4 (6 Aug. 1961): 21.

69 He Rong, "Geming fengbao zhong de yingxiong xingxiang" (The image of the hero in the storm of revolution), Meishu 4 (6 Aug. 1961): 6. 
element to the scene. ${ }^{70}$ The faces of these ordinary miners, which Hou dignified by giving them unity and purpose, show the force of collective action and, most important, in the words of Hou Yimin, "the awakening of class consciousness."71

\section{The Founding of the New Nation}

Dong Xiwen's Founding Ceremony of the Nation triumphantly concludes the visual narrative of CCP history on canvas in the new museum. ${ }^{72}$ In documenting a historic event in contemporary China, Dong's work is highly authentic. The painting was done in the style of the popular New Year print that lends an indigenous flavor through the common technique in traditional folk art of sharp contrasting colors, in this case bright red pillars and lanterns, a blue sky, and white clouds. While the chrysanthemums are a familiar symbol of longevity, the white doves released into the sky signal the return of peace in a land long ravaged by chaos and war. In the middle of Tiananmen Square, a new national flag has been raised, while crowds of hundreds of thousands, surrounded by colorful banners, stand in formation both admiring the chairman and engrossed in his declaration.

Despite his training in Western oil painting, Dong's work was undoubtedly influenced by the traditional New Year prints that the government actively promoted as a popular folk art in the 1950s. "The Chinese people like bright, intense colors," Dong wrote in 1953. "This convention is in line with the theme of The Founding Ceremony of the Nation. In my choice of colors I did not hesitate to put aside the complex colors commonly adopted in Western painting as well as the conventional rules for oil painting." "If this painting is rich in national styles," he continued, "it is largely because I adopted these [native] approaches."73 In 1953 Dong's celebrated painting was widely distributed by the government publication houses along with other New Year prints. It enjoyed great popularity, selling 560,000 copies in three months in its initial printings. ${ }^{74}$

Dong was also innovative and imaginative. In The Founding Ceremony of the Nation, Mao is depicted standing on a carpet. Its surface texture is enhanced by the addition of sawdust. ${ }^{75}$ The confined setting of Tiananmen Gate, enclosed by ancient walls and gates in the early 1950 s, also led Dong to adopt more imaginative interpretations. He eliminated a few pillars in front of Mao to open up the space before him and forge a direct link between the chairman and the adoring crowds assembled in the square. Mao is also directly facing Zhengyang

\footnotetext{
${ }^{70}$ Hou Yimin, "Liu Shaoqi tongzhi he Anyuan kuanggong de gousi," 24.

71 Interviews with Hou Yimin.

72 Wenwu 7 (July 1961), 27-37.

73 Dong Xiwen, "Youhua Kaiguo dadian de chuangzuo jingyan" (How I created The Founding Ceremony of the Nation), Xin guancha (New observer) 21 (1 Nov. 1953): 24-25.

74 Jiang Feng, Jiang Feng meishu lunji, 92.

75 Interviews with Jin Shangyi.
} 
Gate, the main southern entrance into the inner city of the former imperial palace, along the traditional, sacred north-south axis, a symbolic representation of his authority.

Concentric circles are a dominant pattern in Dong's painting, and Mao's centrality in this pattern is unmistakable. No longer a man of action as in the civil war period, Mao appears in a stately manner with an imposing presence. But unlike the real event, where he made the historic announcement surrounded by his closest comrades including Zhu De and Zhou Enlai, in the painting he stands alone, almost in the center, separate from everyone else. His closest comrades, standing to his left, form the innermost circle. The next circle is the assembled audience lined up in the vast square and enclosed by the old city walls that would be demolished in the mid-1950s, greatly enlarging the square. Outside the walls is the distant age-old city, and at the outermost edge the nation beyond shines under a blue sky and bright clouds, promising a glorious future. Without question, Mao is the heart of this symbolic world, and his vision stretches far beyond the capital into the new world.

When The Founding Ceremony of the Nation was first unveiled in 1953, it was enthusiastically received. But it also had its detractors. Xu Beihong, for example, registered disapproval. According to $\mathrm{Xu}$, although the painting did accomplish its political mission by accurately depicting an important historic moment in China, artistically it barely resembled an oil painting because of the predominance of typically rich Chinese colors, with no gradations of warm and cool hues as in the West. ${ }^{76}$ Senior Party leaders, however, viewed the painting approvingly, seeing it as a testament to the young nation's evolving identity and growing confidence. When the painting was exhibited in Zhongnanhai, the Chinese leaders' compound, in April 1953, Mao was quoted as saying, "[The painting shows] a great country, which is China. Our paintings are unsurpassed if measured against others internationally, for we have our own unique national form."77 Hyperbole notwithstanding, Mao's statement points to an important reason why historical paintings were commissioned in the first place: they were forceful vehicles to demonstrate national pride. This issue became more pronounced in the late 1950s and early 1960 s when the Sino-Soviet split prompted Chinese art circles to adopt a more nationalistic stand.

DIFFERENCES BETWEEN CHINESE AND SOVIET PAINTINGS

It is commonly assumed that Chinese history oil paintings closely resembled their Soviet counterparts, but few scholars have analyzed the differences. Certainly the creation of a series of political images in oil paintings was nothing

76 Bo Songnian, Zhongguo yishushi tuji, 253.
77 Ibid. 
new, as all twentieth-century totalitarian systems, including China and the Soviet Union, promoted art as a means of directly expressing their political ideals. ${ }^{78}$ But distinguishing Chinese paintings from the others were the institutional settings under which they were produced and the ways they were closely monitored by the Party. Their increasingly nationalistic tenor also distinguished them from the Soviet model.

Throughout the 1920s the Russian authorities gave no clear direction for the desired form of art under the dictatorship of the proletariat. Only in 1932 did the Soviet Central Committee disband all artistic groups and placed all cultural activities under Party control. ${ }^{79}$ In contrast, the CCP exercised tight control over the Museum of the Chinese Revolution from the very first stage of its construction. The commissioning of paintings took several steps; throughout the process, the Chinese authorities carefully monitored each phase, and the powerful propaganda department supervised all operations.

Negative themes were common on Soviet canvases and were generally regarded as a way to depict historical dialectic struggles in which the socialist camp was eventually triumphant. Two notable examples are Grigori Shegal's The Flight of Kerenski from Gatchina in 1917 (1937-1938, Tretyakov Gallery, Moscow), which depicts the ousting of the prime minister of the provisional government by the Bolsheviks, and the Kukryniksy's (Mikhail Kupriyanov, Porfiri Krylov, and Nikolai Sokolov) The End (1948, Tretyakov Gallery, Moscow), which shows Hitler's death by self-administered poison. Chinese revolutionary history paintings, however, seldom presented enemies as primary subjects. The scene of the defeated Kuomintang troops in Bao Jia's and Zhang Fagen's Great Victory in Huai-Hai is a rarity. Even there, the enemy serves only as a backdrop to the Red Army's victory. Revolutionary paintings generally conveyed positive images, showing major historical events in the most glowing light. This type of commissioned work was meant, in the words of Wang Zhaowen, to extol "revolutionary optimism" (geming leguan zhuyi). It would "distort the revolutionary ideal," Wang added, if the works were visualized in the language of "horror and brutality." In depicting leaders, therefore, Jin Shangyi echoed, "we must do everything we can to avoid making them appear unsightly." ${ }^{81}$ Wang's and Jin's comments are clearly in line with the doctrines of socialist realism, but by stressing positive interpretations almost exclusively, Chinese paintings went a step further than

\footnotetext{
78 Igor Golomostock, Totalitarian Art in the Soviet Union, the Third Reich, Fascist Italy and the People's Republic of China, Robert Chandler, trans. (New York: IconEditions, 1990).

79 Boris Groys, The Total Art of Stalinism: Avant-Garde, Aesthetic Dictatorship, and Beyond, Charles Rougle, trans. (Princeton: Princeton University Press, 1992), 33.

${ }^{80}$ Wang Zhaowen, "Biaoxian renmin qunzhong de yingxiong shidai" (An age of heroism that reflects the people), Meishu 8-9 (Aug.-Sept. 1960): 35.

81 Jin Shangyi, "Chuangzuo Mao zhuxi zai shieryue huiyi shang de tihui," 11.
} 
their Soviet counterparts in giving socialist realism far more dogmatic and restrictive expressions.

In addition to ceremonial portraits of leaders and historical revolutionary themes, oil paintings in the Stalinist era in Russia included landscapes glorifying the motherland, as well as still lifes, although these occupied the lower rung of revolutionary socialist art. One example is Vasily Baksheev's Blue Spring (1930, Tretyakov Gallery, Moscow), a painting of silver birch trees as a symbol of Russia. Chinese painters, on the other hand, focused primarily on leaders and revolutionary themes, and they deemed landscape and still life painting insignificant forms of revolutionary art. As such, paintings depicting Chinese history spanned a much narrower scope than their Russian counterparts. Moreover, Soviet portraits of leaders were heavily influenced by the Russian Orthodox Church and religious icons; as Victoria Bonnell pointed out, leaders often were portrayed with a worker and peasant at their side, similar to the apostles standing beside Christ, as in A. L. Sokolov's 1922 poster, Let the Ruling Classes Shudder before the Communist Revolution. ${ }^{82}$ Paintings representing Chinese revolutionary history, of course, lacked a religious component.

The most significant difference between the two countries may have been the conscious attempt by Chinese artists to instill native colors in their works. They did so in order to produce a national style of oil painting, known collectively as the nationalization (minzuhua) of painting. This attempt was most eloquently described by Dong Xiwen, when he argued in 1957 that Western oil painting had to be nationalized for it to take root in China. Dong warned that if oil painting was not assimilated so that it becomes "part of our blood," the genre will forever remain a "foreign product." 83 But in the 1950 s nationalization was a nebulous concept with numerous meanings - artistic, technical, and political. Artistically, nationalization meant creating a Chinese style of painting by blending indigenous and Western techniques. Dong's adoption of bright colors and ornamental designs following the convention of New Year prints in The Founding Ceremony of the Nation is one example. ${ }^{84}$ Dong was proud of his work, and in his painting, as he stated, he purposely "lessened the contrast between warm and cool colors," and "simplified the extensive gradation of light and dark" - common oil painting techniques_-giving his piece a strong "ornamental effect," typical of traditional Chinese painting. ${ }^{85}$ Others, however, in order to lend their work a more distinctive Chinese look, proposed

\footnotetext{
82 Victoria Bonnell, Iconography of Power: Soviet Political Posters under Lenin and Stalin (Berkeley: University of California Press, 1997), 147.

83 Dong Xiwen, "Cong Zhongguo huihua de biaoxian fangfa tandao youhua de Zhongguofeng" (From the expressive methods of Chinese painting to Chinese characteristics of oil painting), Meishu 1 (1 Jan. 1957): 6.

${ }_{85}^{84}$ Dong Xiwen, "Youhua Kaiguo dadian de chuangzuo jingyan," 25.

85 Ibid.
} 
accentuating the principles of "generality and concentration," ideals long cherished in traditional ink painting. ${ }^{86}$

Technically the concept of nationalization, according to Zhou Enlai, was "tantamount to popularization," meaning that art could be made accessible to the widest possible audience, especially to "workers, peasants, and soldiers." 87 This line of reasoning, of course, closely followed Mao's directive in his 1942 influential "Yan'an Talks," which called for the use of art as a political device to serve the people. ${ }^{88}$

Perhaps even more important, nationalization, politically, reflected the official policy of finding an independent artistic road different from that of the Soviet Union. This became more urgent in the late 1950s, when the relationship between China and the USSR turned antagonistic, and Mao's policy of self-reliance became a guiding principle in the nation's campaign to distance itself from Moscow. In the end, neither art nor technique but politics was at the heart of the nationalization of oil painting. China's search for a distinctive art clearly reflected an affirmation of its independence.

\section{CONCLUSION}

The idea that art can be dangerous and hence must be strictly controlled has been understood since the time of Plato's Republic. Stalin's attack against the avant-garde in the 1930s and Hitler's denunciation of "degenerate art" in 1937 were prompted by the fear of free artistic expression. But throughout history art has been used to serve the interests of those in power. In the case of the PRC, the paintings depicting revolutionary history commissioned by the MCR were the Party's attempt to tell its own victorious history through a medium introduced from the West, and to assert its independence from foreign countries. The museum was a highly controlled political arena, and the paintings were the Party's hegemonic representations of the nation's memory.

Chinese painters were commissioned in successive stages by Party officials to produce works on predetermined subjects, and many of these artists had done so with the utmost devotion and flair. But how much autonomy did the artists enjoy? Despite the dominance of the state, there is no denying that painters retained a modicum of freedom in the use of colors and brushwork in executing their art. Zhan Jianjun, for instance, was heavily influenced by European Impressionists in his experiments with color and light. Similarly, Luo

${ }^{86}$ Wu Zuoren, "Youhua de xinmao" (The novelty of oil painting), Meishu 8-9 (1960): 42.

87 Zhou Enlai, "Zai yinyue wudao zuotanhui shang de jianghua" (Talk at the music and dance forum), in, Wenhuabu wenxue yishu yanjiuyuan, ed., Zhou Enlai lun wenyi (Zhou Enlai on literature and art) (Beijing: Renmin wenxue chubanshe, 1979), 181.

${ }^{88}$ Mao Zedong, "Talks at the Yenan Forum on Literature and Art," in Selected Works of Mao Tse-tung, 3: 69-98. 
Gongliu praised the achievements of Monet, van Gogh, and Matisse. ${ }^{89}$ But notwithstanding their personal tastes and individual styles, their works ultimately had to be subservient to ideological ends or face rejection, as in the case of Jin Shangyi's Farewell. With its rigid doctrines, socialist art could only speak one official language dictated from the top.

In China, revolutionary history paintings were tailored to accommodate the political goals of the national leaders, and thus artistry was stifled. Although we have little information about how Chinese citizens actually viewed these paintings in the MCR, there can be little doubt regarding the precise way the CCP wanted them to be seen. But the subjects the leaders wanted the public to see were constantly in flux, reflecting the perpetual power struggle among the leaders. Paintings in the museum thus enjoyed only a precarious and often fleeting existence. Dong Xiwen's Founding Ceremony of the Nation was not the only casualty of Party infighting. Hou Yimin's Comrade Liu Shaoqi and the Anyuan Coal Miners suffered a similar fate. Hou's painting enjoyed rave reviews when it was first presented in 1961, at a time when Liu Shaoqi's position was affirmed and not problematic. But during the Cultural Revolution in the mid-1960s, when Liu was attacked by the radicals as a "capitalist roader" and removed from power, Hou Yimin also met with criticism and his painting was dropped from the MCR exhibits. Although revolutionary history paintings were visual tales designed to glorify the achievements of the CCP, there was no fixed script. The story was continually subject to reinterpretation according to the shifting political tides.

${ }^{89}$ Liu Xiaochun, Lou Gongliu yishu duihualu, 49. 
Reproduced with permission of the copyright owner. Further reproduction prohibited without permission. 